УДК 377.352

Смоляна Наталя Вікторівна, аспірант лабораторії професійної орієнтації i виховання Інституту професійно-технічної освіти Національної академії педагогічних наук України, м. Київ, e-mail: smolianaya2008@ukr.net

\title{
ВИКОРИСТАННЯ ТЗН У НАВЧАЛЬНО-ВИРОБНИЧОМУ ПРОЦЕСІ ПРОФЕСІЙНОЇ ШКОЛИ В УКРАЇНІ (1960-1991 РР. ХХ СТОЛІТТЯ)
}

\section{Анотація}

Статтю присвячено історико-педагогічному аналізу проблеми використання технічних засобів навчання у навчально-виробничій діяльності закладів профтехосвіти Української Радянської Соціалістичної Республіки (1960-1991рр. $\mathrm{XX}$ ст.). Виходячи 3 позицій поєднання професійного навчання з виробничою працею, обгрунтовано позитивні й негативні аспекти використання технічних засобів навчання у навчально-виробничому процесі. На основі вивчених архівних та літературних матеріалів вищезазначеного періоду доведено, що питанням упровадження, оновлення технічних засобів навчання як важливої складової професійної підготовки робітників у професійно-технічних навчальних закладах приділялася значна увага як на рівні навчальних закладів, так і на рівні держави.

Ключові слова: професійне навчання, виробнича праця, технічні засоби навчання.

Постановка проблеми. Зростання ролі науково-технічного прогресу в усіх сферах життя суспільства, прискорене впровадження автоматизації, механізації $\mathrm{i}$ комп'ютеризації у виробництво в другій половині $\mathrm{XX}$ століття зумовили нагальність підготовки нового типу кваліфікованих робітників, які б не тільки володіли професійними навичками користування цією технікою, а й могли високопродуктивно працювати з нею. Це уможливлювалося за умови поєднання професійного навчання з виробничою працею з використанням технічних засобів навчання (далі ТЗН).

3 початку 60-х pp. XX ст. запровадження ТЗН у закладах професійнотехнічної освіти відкрило нові перспективи для ефективності навчально- 
виробничої діяльності, створило значний пласт навчальної інформації, оперативного її застосування, для розробки нових методик професійного навчання, раціоналізації прийомів праці, самостійної роботи учнів тощо.

Пропонуємо більш детально розглянути проблему впровадження технічних засобів навчання для ефективного поєднання професійного навчання з виробничою працею учнів закладів професійно-технічної освіти.

Аналіз літературних джерел. Проблема впровадження технічних засобів навчання у навчально-виховний процес закладів профтехосвіти широко висвітлювалася в багатьох радянських посібниках із професійної педагогіки, в окремих навчально-методичних виданнях, педагогічних енциклопедіях. Йдеться про праці С. Я. Батишева, Ю. Ф. Зіньковського, М. Ю. Кадемії, Н. Г. Ничкало, О. М. Новікова, В. В. Олійника, В. О. Скакуна, О. М. Царенко та ін. Незважаючи на значний пласт педагогічних напрацювань з різних аспектів використання ТЗН у професійній школі, проблема запровадження технічних засобів навчання у навчально-виробничий процес закладів профтехосвіти зазначеного періоду системно не вивчалася, що й зумовило вибір теми нашого дослідження.

Мета. Ми поставили за мету проаналізувати проблему використання ТЗН у навчально-виробничому процесі закладів профтехосвіти досліджуваного періоду.

Завдання: виокремити й схарактеризувати позитивні й негативні аспекти використання ТЗН у професійній підготовці учнів закладів профтехосвіти.

У контексті поєднання професійної підготовки 3 виробничою працею впровадження технічних засобів навчання на уроках виробничого навчання забезпечує активне сприйняття і засвоєння учнями інформації, повідомленої 3 екрану, за умови ретельної підготовки майстра виробничого навчання до екранізованого заняття, продуманого добору навчальної інформації відповідно 3 освітніми завданнями, 3 урахуванням загального розвитку й індивідуальних особливостей учнів групи. Варто наголосити, що задача майстра виробничого навчання під час демонстрації ТЗН полягає в тому, щоб організувати і звернути увагу учнів на сприйняття й осмислення сутності елементів трудового процесу, а також допомогти встановити зв'язки між трудовими діями й об'єктивними умовами їх виконання (організація робочого місця, здійснення технологічного процесу на відповідному виді обладнання тощо) [2, с. 307]. 
На нашу думку, для здійснення аналізу проблеми впровадження технічних засобів навчання у навчально-виробничий процес необхідно з'ясувати сутність дефініції «технічні засоби навчання». Технічні засоби навчання - це засоби навчання, що складаються 3 екранно-звукових носіїв навчальної інформації й апаратури, за допомогою якої виявляється ця інформація. Варто зазначити, що екранно-звукові засоби поділяються на звукові (аудитивні) - грамзаписи, магнітні записи, радіопередачі; екранні (візуальні) - «німі» кінофільми, діафільми тощо; екранно-звукові (аудіовізуальні) - звукові кінофільми, телепередачі, комп’ютери та ін. [4, с. 905].

Для ефективності поєднання професійного навчання з виробничою працею важливого значення набуває те, що специфіка ТЗН полягає у здатності повідомити таку навчальну інформацію, яку не можна пізнати без спеціальної апаратури, а важливість екранно-звукових засобів - їх документальна основа, фіксація фактів, подій, наукових дослідів тощо [4, с. 905].

Як свідчать результати наукового пошуку, використання ТЗН набуло поширення у практиці професійного навчання у закладах професійно-технічної освіти Української Радянської Соціалістичної Республіки після прийняття закону «Про зміцнення зв’язку школи 3 життям і подальший розвиток системи народної освіти СРСР» (1958 р.) [6, с. 54-55]. Упродовж досліджуваного періоду, у виданих численних нормативно-правових документах 3 реформування ПТО, неодмінно наголошувалося на необхідності збільшення обсягів випуску і забезпечення ТЗН закладів профтехосвіти, широкого їх застосовування у навчально-виробничому процесі. Наприклад, у Постанові ЦК КПРС, Ради Міністрів СРСР «Про подальший розвиток системи професійно-технічної освіти і підвищенні і ролі у підготовці кваліфікованих робітничих кадрів» (травень 1984 р.) наголошувалося на необхідності звернення особливої уваги на підготовку кваліфікованих робітників для створення й експлуатації нової техніки, автоматизованих виробництв із застосуванням комп'ютерів, роботів, мікропроцесорних засобів і гнучких технологій [6, с. 162-169]. Отже, упровадження ТЗН у навчально-виробничу діяльність мало нормативно-правове підгрунтя, а це спонукало до швидких кроків 3 боку керівників, педагогічних та інженерно-педагогічних працівників у питаннях придбання і широкого застосування технічних засобів навчання. 
Аналіз літературних джерел показав, що упродовж 60-х рр. співробітниками відділу професійної педагогіки Всесоюзного науково-дослідного інституту профтехосвіти глибоко вивчалася проблема впровадження ТЗН у навчальновиробничий процес. Науковцями було доведено, що успішне формування загальновиробничих і частково професійних умінь, навичок і складних умінь на різних етапах навчання забезпечується за умови комплексного використання екранних навчальних засобів: інструктивних кінофільмів, кінофрагментів, діафільмів, діапозитивів тощо [2, с. 294-295]. Варто зазначити, що з 1971 р. у створеному в Україні відділі професійно-технічної освіти при Науково-дослідному інституті педагогіки Міністерства народної освіти УРСР було розпочато роботу з наукового обгрунтування використання технічних засобів навчання, їх комплексного застосування у навчальній діяльності учнів [9, с. 65-66].

Оскільки процес становлення професійних умінь залежить від точного i повного формування образу дії (уявлення про мету дії, за допомогою яких способів виконати дію, як здійснити самоконтроль тощо), у контексті поєднання професійного навчання 3 виробничою працею актуальності набуває те, що досліджуваний період характеризується посиленням уваги з боку викладачів спецтехнології та ін. предметів під час навчально-виробничого процесу використовувати тематичні кінофільми, діафільми, кодопроекції тощо. Крім того, ТЗН застосовувалися як додаток до інструктажу, показу трудових дій чи як самостійні джерела інформації для формування в учнів професійних знань і необхідних зорових, слухових, кінестичних уявлень про детальні способи виконання трудових дій [10, с. 6-7]. Так, під час інструктування застосовувалися кодопроекції, кінофрагменти, кінокільцівки, діафільми, які давали змогу пояснити учням особливості правильної постави, тримання інструменту тощо [11, с. 14].

Цінним для нашого дослідження $\epsilon$ те, що використання інформації, закладеної у кінофільмах і діафільмах, підвищує рівень самостійності учнів у процесі виконання ними навчальних, навчально-виробничих і виробничих завдань. В учнів створюється більш ширша орієнтовна основа дій, яка забезпечує самостійне, усвідомлене виконання практичних операцій. У випадку виникнення труднощів вони не тільки можуть звернутися до майстра виробничого навчання (далі $\mathrm{MBH}$ ), але й самостійно отримати додаткову інформацію, що міститься в 
екранних посібниках. Так, інструкційні кінофільми, діафільми та ін. екранні посібники розширюють можливості МВН під час проведення бесіди, так як використання наявної в них інформації дає змогу йому з меншою витратою часу і 3 більшою ефективністю використовувати теоретичні знання учнів, їх уявлення про трудові дії під час пояснення структури і послідовності виконання прийомів, операцій чи видів робіт, які необхідно знати. Разом з тим, що екранні посібники забезпечують активність учнів під час проведення поточного i заключного інструктажів, у процесі навчально-виробничих i виробничих завдань вони забезпечують усвідомленість їх виконання [2, с. 308-309].

Аналіз літературних і архівних джерел $[14$, с. $15 ; 11]$ дозволяє зробити висновок про те, що викладачами і майстрами виробничого навчання упродовж досліджуваного періоду ефективно застосовувалися екранні засоби навчання під час навчально-виробничої діяльності.

Як відомо, однією з найважливіших професійних якостей кваліфікованого робітника є сформований технічний слух, за допомогою якого відбувається визначення на слух технічного стану машин, механізмів, устаткування тощо. 3 огляду на вищезазначене, важливе значення у процесі професійного навчання відіграє застосування звукових засобів навчання. Так, 3 початку 60-х рр. особливого поширення в навчально-виробничому процесі професійно-технічних навчальних закладів набуло застосування грамофонних записів [7, с. 7], які використовувалися для формування технічного слуху, професійних знань, умінь та навичок.

За О. М. Новиковим, формування технічного слуху підпорядковується двом задачам: психологічній і педагогічній. Першою передбачається сформувати технічний слух як психологічну здатність: розрізняти звуки, шуми, характерні для об’єктів техніки, на якій проводиться навчання за специфікою своєї професії. А другою задачею передбачається навчити учнів прийомам слухової діагностики, тобто із зміною шумів чи з виникненням нових, визначати причини несправності технічних об'єктів чи необхідності регулювання відповідних вузлів, систем тощо $[10$, c. 31$]$.

Наголосимо, що окремими типами звукових навчальних посібників були уроки гігієнічної, оздоровчої та виробничої гімнастики [7, с. 7]. 
Аналіз історично-педагогічних джерел показав, що більшість звукових навчальних кінофільмів, які було випущено за замовленням Державного Комітету Ради Міністрів СРСР з ПТО, містили матеріали, складні для сприйняття кіноінформації учнями [2, с. 306]. Вищезазначене свідчить про те, що під час створення цих фільмів не враховувалися значною мірою особливості сприйняття підлітків, рівень їх інтелектуального розвитку тощо.

3 огляду на викладене вище, вважаємо за потрібне зазначити, що під час уроків виробничого навчання, якими передбачався перегляд кінофільмів, учні не засвоювали в певній мірі викладений матеріал. В окремих випадках це відбувалося і тому, що під час перегляду викладачі не звертали увагу учнів на окремі, найбільш важливі, фрагменти кінофільму [13, арк. 30].

Отже, виходячи з вищезазначеного, можна зробити висновок про те, що під час створення екранних засобів навчання нехтування фізіологічними особливостями розвитку учнів, їхніми інтелектуальними можливостями негативно впливало на професійну підготовку учнів. Серед негативних наслідків виокремимо й низький рівень методичної підготовки викладацького складу закладів профтехосвіти.

Як відомо, висока якість підготовки кваліфікованих робітничих кадрів можлива, зокрема, за умови оснащення ТЗН навчальних кабінетів, лабораторій закладів професійно-технічної освіти. Аналіз архівних джерел свідчить, що увагу керівників, інженерно-педагогічних працівників i представників базових підприємств привертали питання придбання технічних засобів навчання [5, арк. 2]. Вважаємо за доцільне навести дані щодо забезпечення закладів профтехосвіти Київським обласним управлінням професійно-технічної освіти (табл. 1) [15, арк. $153]$.

Табличя 1 Забезпеченість технічними засобами навчання ПТУ Киӥвського ОУ професійнотехнічної освіти (1979-1980 н.р.)

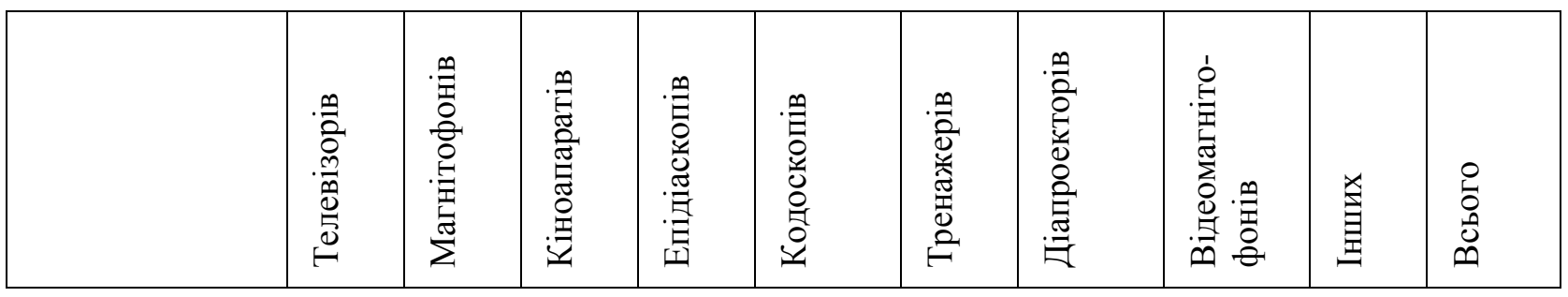




\begin{tabular}{|l|l|l|l|l|l|l|l|l|l|l|}
\hline $\begin{array}{l}\text { Придбано } \\
\text { 01.09.1979 по } \\
\text { 01.08.1980 н. }\end{array}$ & 69 & 23 & 107 & 5 & 69 & 21 & 84 & 7 & - & 385 \\
\hline $\begin{array}{l}\text { Всього } \\
\text { наявних: }\end{array}$ & 136 & 112 & 226 & 66 & 95 & 228 & 288 & 12 & 157 & 1320 \\
\hline
\end{tabular}

Аналіз викладених у табл. 1 матеріалів уможливлює висновок про те, що забезпечення технічними засобами навчання відбувалося повільно, тільки під кінець 70-х рр. обласні управління (далі ОУ), базові підприємства та ін. установи стали приділяти значну увагу цій проблемі.

У цей же період у професійно-технічних навчальних закладах особливого значення набуло навчальне телебачення. Для поєднання професійного навчання 3 виробничою працею важливим є те, що воно знайшло своє застосування під час виробничого навчання, адже система навчального телебачення являла собою ефективний засіб наочного показу всім учням групи (а іноді й усього потоку) робочих рухів, операцій і процесів, пов'язаних 3 виконанням точних робіт 3 використанням дрібних деталей, інструментів та устаткування, складних схем тощо. Навчальне телебачення ефективно використовувалося i під час демонстрування МBН прийомів i процесів, безпосереднє сприйняття яких шкідливе, наприклад для очей (електрогазозварювальники, термісти тощо) [2, c. 134].

Разом 3 тим, ТЗН і використання раціональних методичних прийомів і їх застосування на заняттях не забезпечують повною мірою ефективності уроку, якщо у навчальних майстернях (лабораторіях) не створено необхідних матеріальноорганізаційних умов для перегляду кінофільмів і діафільмів [2, с. 312-313]. 3 огляду на вищезазначене, вважаємо за потрібне зазначити, що досліджуваний період характеризувався посиленням уваги до проблеми обладнання лабораторій, кабінетів необхідним устаткуванням для екранізації уроків. 3 цією метою педагогічними колективами училищ складалися фонотеки, кінотеки. Наприклад, Запорізьке обласне управління професійно-технічної освіти упродовж 1961-62н. р. обладнало по 1-3 кабінетами (усього 68 навчальних кабінетів), для яких було придбано 39 діаскопів, 8 діапроекторів «ЛЕТІ-55» і 12 кіноустановок, виготовлено 98 фонотек, придбано навчальні фільми і кінофільми для проведення екранізованих 
уроків [12, арк. 2]. Водночас, архівні джерела зберігають інформацію про те, що у Черкаському ОУ (1963-64 н. р.) робота зі створення кабінетів для кінофікації уроків здійснювалася незадовільно. У всіх перевірених училищах не було створено жодного кабінету, обладнаного необхідною апаратурою для впровадження кіно в навчальний процес [13, арк. 29].

Виходячи з вищезазначеного, можна зробити висновок, що створення й устаткування кабінетів, майстерень $\mathrm{i}$ лабораторій 3 кінофікації відбувалося нерівномірно. Вивчені матеріали дають підстави для висновку, що не всі училища були забезпечені належною кількістю кінофікованих кабінетів тощо.

Слід зазначити, що питанням забезпечення закладів профтехосвіти технічними засобами навчання приділялася значна увага 3 боку працівників Республіканського навчально-методичного кабінету (далі РНМК). Наприклад, тільки у 1967 р. працівниками РНМК було введено у навчальний процес понад 2,5 тис. динамічних наочних посібників, обладнано технічними засобами понад 500 навчальних майстерень, 450 лабораторій, 2800 навчальних кабінетів (табл. 2).

\section{Забезпечення РНМК закладів профтехосвіти УРСР технічними засобами навчання (1967 н. р.)}

\begin{tabular}{|c|c|c|c|c|c|c|c|c|}
\hline \multirow[t]{2}{*}{$\begin{array}{l}\text { Придбано } \\
\text { Республіканським } \\
\text { навчально- } \\
\text { методичним } \\
\text { кабінетом }\end{array}$} & 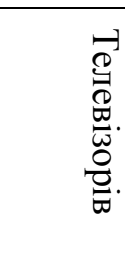 & 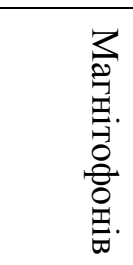 &  & 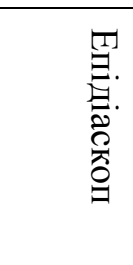 & 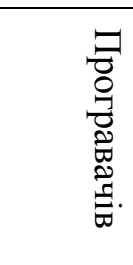 & 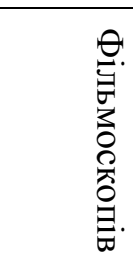 & 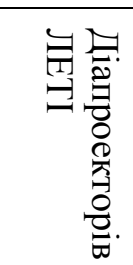 & 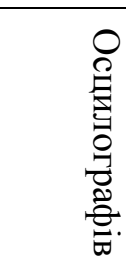 \\
\hline & 1080 & 1280 & 1909 & 1029 & 792 & 1261 & 2311 & 122 \\
\hline
\end{tabular}

Джерело: складено автором на основі опрацювання архівних матеріалів [3, арк. 106].

Для нашого наукового пошуку доцільно звернутися до позитивного досвіду спільної роботи Державного комітету Ради Міністрів УРСР і Республіканського навчально-методичного кабінету з питань поширення позитивного досвіду роботи окремих училищ і обласних управлінь щодо впровадження ТЗН у навчальновиховний процес. Як свідчить аналіз історично-педагогічної літератури, упродовж досліджуваного періоду видавалися численні навчально-методичні видання 3 
проблем упровадження ТЗН у навчально-виховний процес, брошури 3 досвіду роботи тощо. Так, з початку 80-х рр. у діяльність професійно-технічних закладів України упроваджувався досвід роботи Львівського і Хмельницького обласних управлінь «Комплексне застосування ТЗН у навчально-виховному процесі» тощо [5, арк. 10, 15].

Соціально-економічний розвиток УРСР у другій половині 80-х рр. минулого століття актуалізував проблему підготовки кваліфікованих робітників для тогочасних автоматизованих виробництв із застосуванням комп'ютерів, роботів, мікропроцесорних засобів тощо. Йшлося про підготовку робітників, які б досконало володіли прийомами роботи на цій техніці, могли іiі кваліфіковано обслуговувати і ремонтувати. Проте, у навчальний процес професійно-технічних навчальних закладів освіти УРСР комп'ютери почали запроваджуватися лише 3 другої половини 80-х рр. У закладах профтехосвіти створювалися необхідні умови для вивчення інформатики й обчислювальної техніки, вводилися нові предмети: «Автоматизація виробництва на основі електронно-обчислювальної техніки» тощо $[1$, c. 60$]$.

Вищезазначене уможливлює доречність згадування про те, що ідея використання комп'ютерів у навчальному процесі належить видатному педагогу, психологу, математику і програмісту Сеймуру Пейперту (Seymour Papert) (60-i pp. ХХ ст.) Упродовж багатьох років він ініціював й сприяв просуванню інноваційної програми, згідно якій «комп’ютери, а не папір з олівцями, стануть домінуючими інструментами для освіти». На думку Сеймура Пейперта, комп’ютери необхідні не тільки для навчання, а й розвитку творчого потенціалу учня [16].

У контексті проблеми поєднання професійного навчання 3 виробничою працею варто виокремити основні форми роботи учнів і педагогів 3 використанням комп'ютера, які набули поширення у професійно-технічних навчальних закладах досліджуваного періоду [8, с. 20-21, 25-26, 31-35, 42-43]:

- використання комп’ ютера під час навчання учнями і майстром виробничого навчання для організації й оцінювання навчально-виробничої діяльності учнівських виробничих бригад (кількість виготовлених деталей, операцій, статистичних даних);

- складання інженерно-педагогічними працівниками училищ програм для 
обробки конкретних деталей (за індивідуальними завданнями 3 подальшим введенням і обробкою програм на відповідних пультах верстатів);

- складання учнем за допомогою комп’ютерних програм технологічних карт з виготовлення деталей із застосуванням основних видів їх подальшої обробки;

- використання функції «комп’ютер-екзаменатор» для самоконтролю учнів i контролю знань з предметів професійного циклу, виробничих процесів тощо;

- застосування ЕОМ під час професійного навчання 3 метою визначення причин браку чи несправності автоматичного обладнання тощо.

Зазначимо, що 3 початку 80-х pp. у закладах профтехосвіти УРСР активізувалися педагогічні експерименти з визначення ефективності впровадження технічних засобів навчання «нового покоління» у навчально-виробничий процес. Наприклад, у результаті одного з таких експериментів, який проводився у міському ПТУ №4 м. Вінниці, було визначено ефективні методичні прийоми із застосуванням програм обчислення для закріплення в учнів навичок роботи 3 обчислювальними машинами. Так, викладачами Р. С.Гуревичем та М. Ю. Кадемією у професійному навчанні широко застосовувалися мікрокалькулятори тощо [14, арк. 15].

Висновки. На початку 60-х років XX ст. питанням упровадження, оновлення технічних засобів навчання як важливої складової професійної підготовки робітників у ПТНЗ почала приділятися значна увага як на рівні навчальних закладів, так і на рівні держави. Створені кабінети кінофікації, використання технічних засобів навчання у ході навчально-виробничої діяльності учнів сприяло поглибленню професійних знань учнів, практичної спрямованості навчального процесу ПТНЗ, уникненню формалізму у викладанні предметів професійнотехнічного циклу, ознайомленню учнів з тогочасною технікою, будовою деталей, а також залученню учнів до виробничої праці. Серед негативних характеристик запровадження ТЗН у досліджуваний період слід виокремити нерівномірність забезпечення училищ ними. Спостерігалися й недоскональне володіння викладачами i майстрами виробничого навчання методиками раціональних методичних прийомів застосування ТЗН на заняттях, а головним недоліком роботи окремих викладачів і МВН була низька методична підготовка до уроків.

Результати нашого наукового пошуку уможливлюють висновок про те, що 
80-і роки минулого століття можна виокремити як етап удосконалення методів прогнозування і планування комплексного економічного і соціального розвитку системи професійно-технічної освіти республіки 3 широким застосуванням автоматизованих систем управління на базі електронно-обчислювальної техніки. Це зумовило активізацію пошуків нових форм і методів професійного навчання 3 використанням комп’ютерів. Також набули поширення педагогічні експерименти 3 визначення ефективності впровадження ТЗН «нового покоління» у навчальновиробничий процес.

Наша публікація не вичерпує всіх аспектів порушеної проблеми. До перспективних напрямів наукових пошуків належить вивчення ролі інструктора, майстра виробничого навчання i викладача спецдисциплін в організації професійного навчання з виробничою працею у закладах профтехосвіти.

\section{Список використаних джерел}

1. Актуальные проблемы перестройки и совершенствования управления профессионально-техническим образованием в Украинской СССР в свете требований XXVII съезда КПСС и XXVII съезда Компартии Украины / отв. ред. Н. Г. Ничкало. - К. : Вища шк., 1987. - 102 с.

2. Дидактика производственного обучения / под ред. О. Ф. Федорова. М. : Высш. шк., 1973. - 416 с.

3. Довідки облуправлінь ПТО про хід виконання наказу Держкомітету від 15 травня 1967 р. №42 «Про стан підготовки робітників у навчальних закладах» 1967 р. // Центральний державний архів вищих органів управління України у м. Києві (далі - ЦДАВО). - Ф. 4609, оп. 1, спр. 794, 108 арк.

4. Зіньковський Ю. Ф. Технічні засоби навчання / Ю.Ф. Зіньковський // Енциклопедія освіти / АПН України; гол. ред. В. Г. Кремень. - К. : Юрінком Інтер, 2008. - C. 905-906.

5. Інформації в ЦК Компартії України, Раду Міністрів УРСР, Президію Верховної Ради УРСР про покращення якості підготовки кваліфікованих робітників, удосконалення навчального процесу тощо. 1980 р. // ЩДАВО. - Ф. 4609, оп. 1, спр. 1761, 43 арк.

6. КПСС, Советское государство о подготовке молодой смены рабочего класса. 1940-1987 гг. / Сост. Г. И. Терещенко, И. Ф. Курас, Н. Г. Ничкало и др. - К. 
: Вища шк., 1988. - 416 с.

7. Использование средств звукозаписи в учебном процессе : метод. пособ. для средних ПТУ / Э. О. Конокотин, Д. И. Полторан, Л. Д. Цесарский, Л. С. Якушина. - 2-е изд. перераб. и доп. - М. : Высш. шк., 1984. - 151 с.

8. Использование ЭВМ в учебном процессе при подготовке рабочих : тезисы докладов и сообщений Республиканского научно-практического семинара НИИ школ, отдел профтехобразования. - М., 1990. - 82 с.

9. Ничкало Н. Г. Трансформація професійно-технічної освіти України : монографія / Н. Г. Ничкало. - К. : Педагогічна думка, 2008. - 200 с.

10. Новиков А. М. Применение технических средств в процессе производственного обучения / Александр Михайлович Новиков. - М. : Высш. шк., 1979. - 71 с. - (Б-чка мастера производственного обучения).

11. Пекарська 3. П. Використання технічних засобів на уроках. (3 досвіду роботи Дніпропетровського ПТУ №1) / Зоя Петрівна Пекарська. - К. : Будівельник, 1966. - 44 c.

12. Справка Запорожского ОУ ПТО о выполнении «Закона об укреплении связи школы с жизнью» за 1961-62 г. // ЦДАВО. - Ф. 4609, оп. 1, спр. 570, 10 арк.

13. Справки о проверке состояния производственной практики в учебных заведениях профтехобразования за 1963-64 уч. год. // ЦДАВО. - Ф. 4609, оп. 1, спр. 659, 53 арк.

14. Статотчеты областных управлений профтехобразования об итогах учебной работы средних профтехучилищ за 1979/80 учебный год (ВинницкоеДонецкое). // ЩДАВО. - Ф. 4609, оп. 1, спр. 1745, 198 арк.

15. Статотчеты областных управлений профтехобразования об итогах учебной работы средних профтехучилищ за 1979/80 учебный год (ЖитомирскоеКиевское). // ЦДАВО. - Ф. 4609, оп. 1, спр. 1746, 190 арк.

16. Papert misses 'Big Ideas' of the good old days in AI [Електронний ресурс]. - Режим доступу : <http://web.mit.edu/newsoffice/2002/papert.html>. - Загол. з екрана. - Мова англ.

\section{ИСПОЛЬЗОВАНИЕ ТСО В УЧЕБНО-ПРОИЗВОДСТВЕННОМ ПРОЦЕССЕ ПРОФЕССИОНАЛЬНОЙ ШКОЛЫ В УКРАИНЕ (1960-1991 ГГ. ХХ СТОЛЕТИЯ)}


Смоляная Наталья Викторовна, аспирант лаборатории профессиональной ориентации и воспитания Института профессионально-технического образования Национальной Академии педагогических наук Украины, г. Киев, e-mail: smolianaya2008@ukr.net

\section{Аннотация}

Статья посвящена анализу проблемы использования технических средств обучения в учебно-производственной деятельности учреждений профтехобразования Украинской Советской Социалистической Республики (19601991 гг. ХХ ст.). Исходя из позиций соединения профессионального обучения с производительным трудом, обоснованы позитивные и негативные аспекты использования технических средств обучения в учебно-производственном процессе. На основе изученных архивных и литературных материалов вышеназванного периода доказано, что вопросам введения, обновления технических средств обучения как важной составляющей профессиональной подготовки работников в профессионально-технических учебных заведениях уделялось значительное внимание как на уровне учебных заведений, так и на уровне государства.

Ключевые слова: профессиональное обучение, производительный труд, технические средства обучения.

\section{USE OF TECHNICAL LEARNING TOOLS IN EDUCATIONAL- PRODUCTIVE PROCESS OF PROFESSIONAL SCHOOL IN UKRAINE (1960-1991 XX OF CENTURY)}

Natalia V. Smoliana, PhD student, Laboratory of professional orientation and education of the Institute of Professional Orientation and Education of NAPS of Ukraine, Kyiv, email: smolianaya2008@ukr.net

\section{Resume}

The article is devoted to the analysis of a problem of the use of technical learning tools in educational-productive activity of establishments of vocational education of Ukrainian Soviet Socialistic Republic (1960-1991 XX of item). Coming from positions of connection of the vocational training with productive labour, the positive and negative 
aspects of the use of technical learning tools are proved in the educational-productive process of students. Based on the study of archival and literary materials of abovementioned period, it is proved that the issues of introducing, updating technical training as an important component of training of workers in vocational education has received considerable attention both at school and at the state level.

Keywords: vocational training, productive labour, technical learning tools

Матеріал надійшов до редакції 08.02.2011 р. 